\title{
Reposisi kecerdasan \\ Case study: mendapatkan desain yang baik, dan berdaya hidup dalam desain produk
}

\author{
RAMM Pandansari Kusumo,*
}

Program Studi Desain Produk, Institut Seni Indonesia Yogyakarta, Indonesia

\begin{abstract}
Design is a plan arising from a requirement, through planning, creative ideas and ideas are treated with a combination of art, science and technology, it is expected to be born as a good design. Processing good design will produce an innovation of design that can bring a positive image to the community/market. In the era of global competition, creative behavior is not enough just to use the intelligence of the mind, but also other intelligence that it takes powerful intelligence levitation. Both will be intertwined in the search for new forms that can create trends in the world. Local intelligence has proven able to produce valuable works, this time the intelligence of knowledge is needed, not just transformation of mind, to be able to create the artwork.
\end{abstract}

Keywords: design, innovation, intelligence of mind, levitation, trends

\begin{abstract}
Abstrak
Desain adalah sebuah rencana yang timbul dari suatu kebutuhan, melalui perencanaan, ide kreatif dan gagasan yang diolah dengan mengkombinasikan seni, pengetahuan dan teknologi maka diharapkan akan lahir suatu desain yang bagus. Pengolahan desain yang bagus akan menghasilkan inovasi desain yang dapat membawa imej positif terhadap masyarakat/ pasar. Di era persaingan global laku kreatif tidak cukup hanya dengan menggunakan kecerdasan pikiran, akan tetapi dibutuhkan juga kecerdasan lain yaitu kecerdasan yang berdaya levitasi. Keduanya akan akan berkelindan dalam mencari bentuk-bentuk baru yang dapat menciptakan tren-tren di dunia. Kecerdasan lokal sudah terbukti mampu menghasilkan karya-karya adiluhung, saat ini dibutuhkan transformasi kecerdasan bukan dengan transformasi pikiran untuk dapat menciptakan transformasi seni.
\end{abstract}

Kata kunci: desain, inovasi, kecerdasan pikiran, levitasi, tren

\section{Pendahuluan}

Semua yang ada didunia ini memiliki titik kulminasi dan saling mengikat satu sama lain. Begitu juga halnya dengan desain dan dunia usaha, untuk itu dibutuhkan kreativitas desain dalam menciptakan inovasi guna memenuhi kebutuhan pasar. Dalam makalah pidato ilmiah Suastiwi Triatmojo menuliskan bahwa:

Desain adalah proses menumbuhkan ide kreatif sampai dengan perumusan dan penggambaran sebuah solusi (jalan keluar) untuk memenuhi kebutuhan hidup manusia, sementara inovasi adalah pelaksanaan mewujudkan ide yang sudah digambarkan tersebut. Desain adalah cara mengatasi batasan dan kendala, menyatukan imajinasi dan pertimbangan rasional sehingga gagasan dapat terformulasi menjadi rancangan atau temuan baru (invensi). Inovasi adalah langkah lanjutan dari invensi dan mengubahnya menjadi produk, pelayanan atau proses nyata yang dapat dibuat dan dipasarkan oleh perusahaan (Suastiwi, 2013)

Kemampuan kreativitas desainer ditentukan dari keahliannya dalam mengkombinasikan seni, pengetahuan, dan teknologi, sehingga dari kemampuannya itu dapat menciptakan suatu desain

\footnotetext{
* Koresponden penulis e-mail : pandansarikusumo@gmail.com
} 
yang bisa dinyatakan sebagai desain yang bagus (good design).

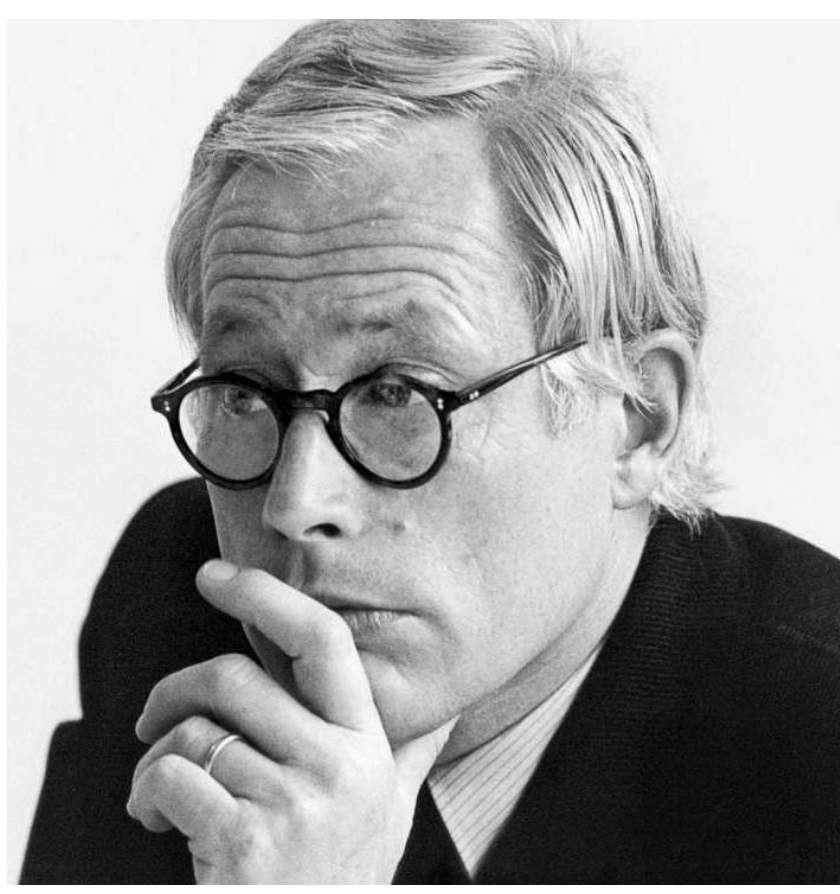

Good design is...

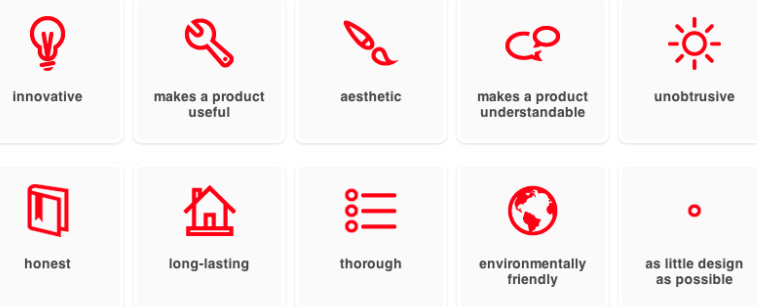

Gambar 1. Dieter Rams dan 10 prinsip desain yang baik (Sumber: https://www.vitsoe.com/gb/about/good-design)

Menurut Dieter Rams, seorang desainer industri senior dan ternama dari Jerman, dalam buku Pengembangan Desain Produk menyebutkan bahwa, ada 10 prinsip dasar yang harus terkandung dalam sebuah desain yang bagus. Kesepuluh prinsip tersebut adalah: (1) Inovatif, yaitu apakah sebuah produk membuka kesempatan baru atau tidak; (2) Kegunaan, yaitu apakah sebuah produk dibeli untuk digunakan atau tidak, dan bagaimana sebuah produk memuaskan pengguna dengan fungsi yang dimilikinya; (3) Estetis, yaitu apakah tampilan estetis dari sebuah produk merupakan bagian integral dari fungsi yang ditawarkan; (4) Mudah dimengerti, yaitu apakah sebuah produk dapat mengkomunikasikan fungsinya dengan baik kepada pengguna secara mandiri; (5) Apa adanya, yaitu bahwa produk dibuat untuk dipergunakan dan memiliki prinsip sebagai alat, bukan elemen estetis atau karya seni. Maka nilai estetis yang dikandung tidak berlebihan dan harus memiliki maksud yang jelas; (6) Jujur, yaitu seperti pada poin sebelumnya, sebuah produk harus menepati "janji" yang ditawarkannya kepada pengguna dengan harga yang pantas; (7) Berdaya tahan, yaitu sebuah produk yang baik, memiliki daya tahan yang cukup, walaupun tidak dibuat untuk abadi, namun tidak mudah tergantikan dengan pergerakan trend yang cepat; (8) Menyeluruh. Setiap detail yang terkandung pada sebuah produk harus dilakukan sebagai pencerminan penghormatan kepada pengguna; (9) Ramah lingkungan. Sebuah produk dapat memberikan kontribusi yang baik terhadap kelestarian lingkungan, meminimalisir penggunaan energi dan sumber daya, dan tidak menyebabkan polusi (baik secara visual maupun secara fisik) sepanjang siklus keberadaannya; (10) Sederhana. Sebuah produk sebaiknya dibuat sesederhana mungkin (Rams, 2013).

Dari kesepuluh kriteria tersebut diatas dapat diketahui, bahwa dalam membuat suatu desain produk, seorang desainer selain dibutuhkan dari keahliannya dalam mengkombinasikan seni, pengetahuan dan teknologi juga dibutuhkan logika, rasionalitas, imajinatif dan rasa

\section{Bahan dan Metode}

Realita adalah sesuatu pemaknaan dari apa yang dilihat, didengar dan dirasakan. Dalam kajian bio psikologi, realita terbentuk dari respon panca indera yang diteruskan untuk diproses dalam otak, sehingga menghasilkan sesuatu yang dinamai pikiran.

Dalam dunia kedokteran biasa digunakan istilah hemisferic assymetris, yaitu suatu istilah yang dipakai untuk menyebutkan belahan otak kiri dan belahan otak kanan. Respon panca indera yang diteruskan untuk diproses dalam otak belahan kiri menghasilkan apa yang dinamakan pikiran sadar, sedangkan respon panca indera yang diproses dalam belahan otak kanan dinamakan pikiran bawah sadar. Pikiran inilah yang melandasi suatu perilaku, perbuatan, tindakan dan keputusan yang diambil atau dilakukan. Belahan otak kiri dan belahan otak kanan memiliki struktur yang berbeda, perbedaan struktur otak itu menjadikan masing-masing belahan memiliki fungsi yang berbeda. Walaupun demikian, kedua belahan itu bekerja paralel dan saling mempengaruhi. Perbedaan struktur dan fungsi otak dapat diamati dari dua macam cara berpikir, yaitu berpikir secara rasional atau linier (belahan otak kiri) dan berpikir imajiner / lateral (belahan otak kanan). Dari perbedaan cara berpikir inilah, maka dalam dunia ilmu pengetahuan didapati 
realitas sosial yang dapat ditangkap panca indera dan bisa dijelaskan secara rasional (Pheuneumena), dan ada realitas sosial yang dapat ditangkap panca indera tapi tidak bisa dijelaskan secara rasional (neumena). Dengan kecerdasan yang dimiliki oleh manusia, maka neumena bisa berubah menjadi pheneumena. Sebagai contoh, jika kita membicarakan tentang handphone pada saat handphone belum diciptakan, maka orang tidak akan percaya dan mungkin dianggap takhayul bahkan musyrik.

Melalui pengamatan, manusia masuk kedalam zona berpikir imajiner/lateral, artinya saat melakukan pengamatan pikiran fokus pada obyek tertentu dan mengabaikan yang lain. Pada kondisi inilah pikiran masuk ke dalam kondisi bawah sadar. Semakin dalam pengamatan yang dilakukan, maka semakin jelas gambaran mental yang dihasilkan oleh pikiran bawah sadar, karena fungsi dari pikiran bawah sadar adalah menghasilkan gambaran mental. Sehingga semakin mudah bagi belahan otak kiri menterjemahkannya secara sistematik scientific atau memunculkannya sebagai ide atau gagasan.

\section{Hasil dan pembahasan}

Pengembangan pengetahuan dan teknologi sangat membutuhkan kemampuan berpikir linier (dengan belahan otak kiri) dan kemampuan berpikir lateral (dengan belahan otak kanan) karena dari berpikir linier itu menghasilkan apa yang dimaknai sebagai rasionalitas. Adapun inti dasar dari rasionalitas adalah dapat terukur dan dapat dibandingkan untuk menghasilkan sesuatu yang lebih efektif, efisien, nyaman dan menguntungkan. Dimana faktor tersebut sangat dibutuhkan dalam pengembangan penciptaan suatu desain, dalam hal ini khususnya desain produk. Sangat terasa pada desain-desain produk yang berbasis teknologi seperti TV, AC, Kulkas, Hand Phone dan lain-lain.

Dalam fenomena dunia ilmu pengetahuan, dari jaman renaisance hingga saat ini, kecerdasan hanya dimaknai dari ruang sekitar otak yang area kerjanya harus bisa dinyatakan secara faktual, riil, konkrit dan terukur. Bahkan kecerdasan dari ruang sekitar otak itupun juga memiliki ukuran, yang dinamakan dengan IQ (Intelegent Quotient). Otak seakan-akan menjadi penguasa tunggal dalam kecerdasan manusia. Dengan kecerdasan manusia memenuhi keingintahuan dan kebutuhan hidupnya yang tanpa batas, bahkan sampai merambah ke hal-hal yang tidak bisa dinyatakan secara faktual, riil, konkrit, dan terukur. Saat inilah otak dipaksakan untuk menjawab hal-hal yang sebenarnya sudah melampaui batasan-batasannya. Otak memang berada dibagian tubuh paling atas manusia tepatnya didalam tengkorak. Tapi otak bukanlah satu-satunya mahkota kecerdasan manusia. Otak hanyalah organ tubuh manusia yang menghasilkan pikiran, sedangkan pikiran hanya menghasilkan rasionalitas dan gambaran mental yang merupakan bahan baku kreativitas. Dengan kreativitas inilah pikiran berupaya memenuhi keingintahuan dan kebutuhan dengan melahirkan suatu ide gagasan tentang EQ (Emotional Quotient) dan SQ (Sentience Quotient) . Yang sebenarnya EQ dan SQ ini hanyalah kepanjangan tangan dari pikiran, untuk menggapai hal-hal yang diluar batas kemampuannya. Diibaratkan EQ dan SQ seperti orang buta yang sedang mengamati seekor gajah. Dan akibat dari pemaksaan wilayah kerja otak inilah terjadi pengkaburan makna antara kecerdasan dan pikiran.

Bagaimana mungkin akan tercipta kembali karyakarya adiluhung dan bagaimana mungkin suatu karya desain produk akan memenuhi kriteria dalam 10 prinsip good design bila dalam proses penciptaan karya-karya itu tetap hanya berkutat dan menarik ulur hanya pada satu kecerdasan, yaitu kecerdasan pikiran. Dalam menciptakan suatu karya seni, untuk berkreasi/mencipta perlu melakukan eksplorasi dan pengembaraan, tidak hanya terbatas pada mikro kosmos saja tapi juga masuk ke dalam makro kosmos, bahkan maha kosmos. Untuk dapat masuk ke dalam wilayah makro dan maha kosmos diperlukan piranti lain selain kecerdasan pikiran, walaupun saat ini baru sebatas numena. Hasil dari eksplorasi dan pengembangan kreativitas yang dilakukan bersama dengan kecerdasan lain adalah saripati dari mikro, makro dan maha kosmos yang terekspresikan pada sebuah karya adiluhung.

Bagi dunia desain produk yang prosesnya dilakukan melalui kecerdasan total, desain dari produk itu akan sanggup menjadi good desain yang kriterianya dapat melebihi 10 prinsip dasar good desain seperti yang diungkapkan oleh Diters Ram, tetapi desain produk itu akan memiliki 11 prinsip desain karena adanya penambahan prinsip daya levitasi pada desain tersebut.

Daya levitasional adalah daya yang menggerakkan sesuatu untuk bergerak melawan daya gravitasional.(Marianto, 2015)

Daya levitasional dalam konteks seni dapat dianalogikan sebagai daya yang menarik keluar antusiasme dari bawah sadar atau sebagai daya yang merangsang pemunculan imajinasi ke tingkat kesadaran atau sebagai daya yang merangsang terbangunnya keinginan seseorang untuk melakukan sesuatu yang sesuai rangsangan yang ditimbulkan oleh suatu subyek. ( Marianto, 2015). 


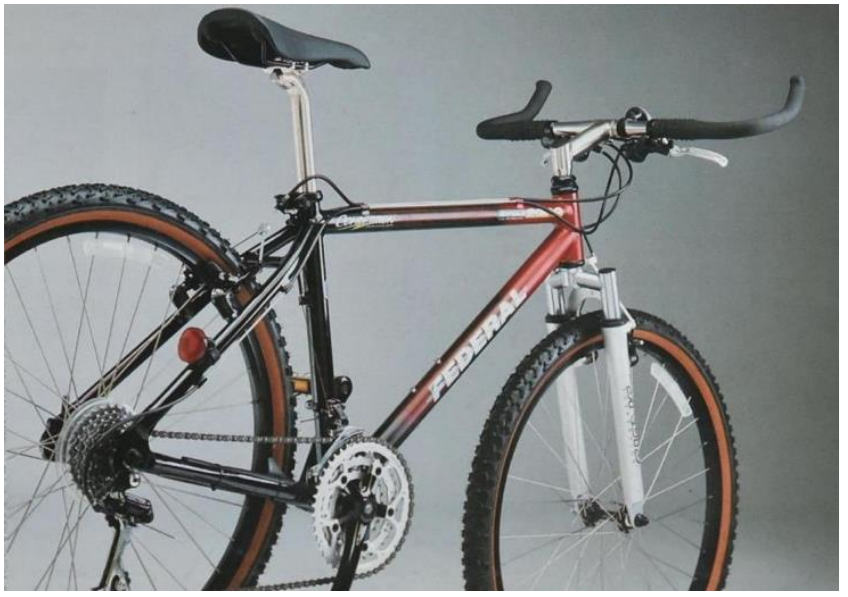

Gambar 2. Sepeda Federal

(Sumber: https://gussur.com/2016/03/30/sekelumit-sejarahsepeda-Federal/)

Jika desain produk itu memiliki daya levitasi, maka desain produk itu bisa menggeliat, mengangkat inovasi sehingga tidak hanya mengikuti trend atau memenuhi pesanan dan kebutuhan saja, tetapi akan menggeliat menciptakan trend dan mampu memberi pencerahan bagi hukum-hukum ekonomi, karena desain-desain itu memiliki daya hidup. Sebagai contoh seperti apa yang pernah terjadi pada kisaran tahun 1985, perusahaan otomotif terkemuka di Indonesia memasarkan produk sepeda yang bermerk Federal dan dikenal dengan jenis sepeda MTB (Mountain Bike). Ciri khas dari produk sepeda itu adalah memiliki rangka yang besar, yang tidak didapati pada jenis-jenis sepeda merk lain pada masa itu (Gambar 2). Kehadiran sepeda Federal itu mampu menghidupkan kembali kesadaran masyarakat akan alat transportasi yang dinamakan sepeda, memotivasi masyarakat untuk berolahraga dalam hal produk sepeda itu berhasil mempengaruhi tingkah laku dan psikologi masyarakat. Sehingga bermunculanlah klub-klub sepeda di masyarakat yang berdampak pada menggeliatnya kembali ekonomi para pedagang, pengusaha, dan bengkel-bengkel sepeda sampai saat ini. Jika diamati dalam kajian desain produk, untuk memproduksi sepeda pada masa itu sangat beresiko ekonomi yang tinggi. Karena kondisi pasar saat itu tidak mencerminkan kebutuhan akan sepeda. Pada masa itu produk sepeda motor bebek sedang hebathebatnya berinovasi dan mendapatkan respon yang baik dari pasar. Faktanya kehadiran produk sepeda Federal itu dapat menciptakan dan mengkondisikan pasar menjadi membutuhkan. Desain sepeda Federal itu masuk kedalam kriteria desain yang baik karena kualitas yang prima, dikemas dan dipasarkan melalui perusahaan yang memiliki good will (kemampuan lebih diatas perusahaan lain yang sejenis) membuat desain sepeda itu semakin memiliki daya hidup.
Berikut gambar sepeda Federal yang ada pada tahun 1985 serta beberapa contoh sepeda yang muncul kemudian setelahnya.

Ilmu, pengetahuan dan seni merupakan produk kecerdasan. Pemaknaan ilmu, pengetahuan dan seni saat ini adalah buah dari satu kecerdasan yaitu pikiran. Pemaknaan pengetahuan dan ilmu pengetahuan adalah berbeda, tetapi sering disamakan dan ditumpangtindihkan dalam penggunaannya. Begitu pula dengan seni dan pengetahuan, serta antara seni dan teknologi. Menurut Kushendrawati dalam buku Psikologi Raos yang dituliskan oleh Ryan Sugiharto dikatakan bahwa,

Pengetahuan adalah berbagai hal yang ditemui, didapat oleh seorang subyek terhadap obyeknya melalui panca indera, kemudian disimpan untuk pengalaman dirinya sebagai subyek. Sedangkan ilmu pengetahuan atau sering disebut ilmu adalah kumpulan pengetahuan yang sudah disistematisasikan sedemikian rupa, sehingga logis, metodis, teoritism memiliki obyektifitas, dan universal (Sugiharto, 2012).

Pengetahuan itu didapat dan ditemui dari sesuatu yang dilihat, didengar dan dirasa oleh panca indra untuk seterusnya disimpan diotak kiri sebagai memori jangka pendek, kemudian disimpan di otak kanan untuk menjadi memori jangka panjang. Proses menjadikan memori jangka panjang tersebut adalah dengan terlebih dahulu menjadikan gambaran mental dan untuk selanjutnya gambaran mental tersebut dimaknai. Gambaran mental yang sudah dimaknai itulah yang dilabelkan sebagai pengalaman. Sedangkan kumpulan pengalaman yang tersimpan diotak kanan, dibawa kembali ke otak kiri untuk disistematisasikan sedemikian rupa agar bisa di keluarkan melalui panca indra menjadi bahasa, keputusan, ide dan gagasan itu disebut ilmu. Dari mekanisme pengetahuan dan ilmu ini lahirlah pengamatan-pengamatan yang diistilahkan menjadi kognitif rasionalitas, logika, imajinasi, ilusi, khayal, dan kreativitas. Kognitif adalah pengamatan yang berfokus pada panca indra ke otak atau sebaliknya, otak ke panca indra. Rasionalitas dan logika pada esensinya adalah istilah yang digunakan untuk menyatakan sesuatu yang berfokus pada proses sistematika yang terjadi di otak kiri. Imajinasi, ilusi dan khayalan adalah suatu istilah yang berfokus tentang gambaran mental yang ada di otak kanan.

Ditinjau dari mekanisme pikiran ini dapat disimpulkan, bahwa kreativitas adalah hasil dari berkelindannya antara logika dan imajinasi. Jika ditinjau dari fungsi kerja otak, kreativitas merupakan hasil dari hubungan timbal balik antara otak belahan kiri dan otak belahan kanan, baik seni maupun 
pengetahuan memiliki esensi yang sama dalam kreativitas.

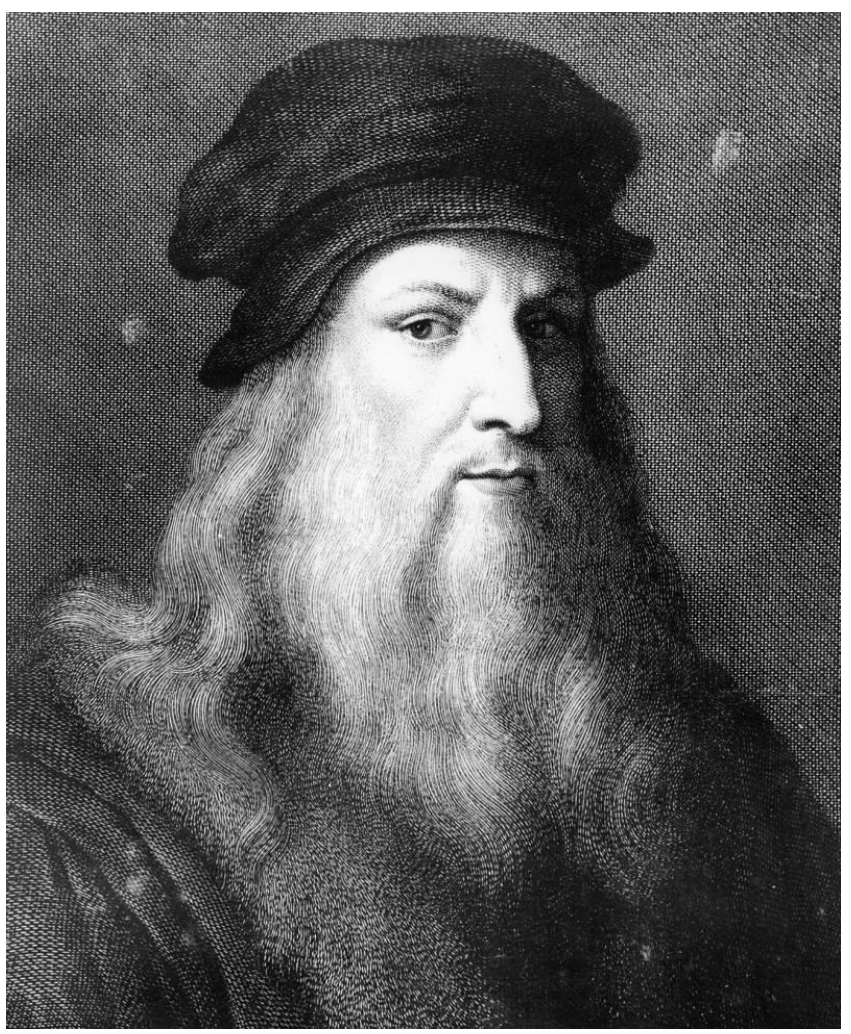

Gambar 3. Leonardo Da Vinci

Leonardo da Vinci ( 1452-1519) dalam tulisan Dwi Marianto, menyatakan bahwa untuk mengembangkan suatu pemikiran yang komplit, belajarlah ilmunya seni dan pelajarilah pula seninya ilmu. Belajarlah bagaimana melihat dan mengamati, sadarlah bahwa segala sesuatu itu saling berhubungan (berkelindan) (Marianto, 2015).

Demikian juga menurut Da Vinci dalam tulisan Dwi Marianto mengatakan bahwa Da Vinci sudah bisa melihat sains dan seni itu setara sebagaimana logika dan imajinasi (Marianto, 2015). Atmosfir kreativitas antara seni dan pengetahuan yang membuat keduanya berkesan berbeda, karena atmosfir kreativitas pengetahuan adalah keingintahuan (self-curriousity) di mana belajar merupakan kecenderungan dalam diri manusia untuk mengadakan petualangan pengalaman. Sedangkan atmosfir kreativitas seni adalah sensasi rasa dalam rasa, yaitu sebagai daya untuk merangsang emosi. Sensasi didapat bukan dari respon panca indera tetapi didapat dari kecerdasan tubuh dalam mengkolaborasikan pengalaman rasa yang pernah ditangkap panca indera.

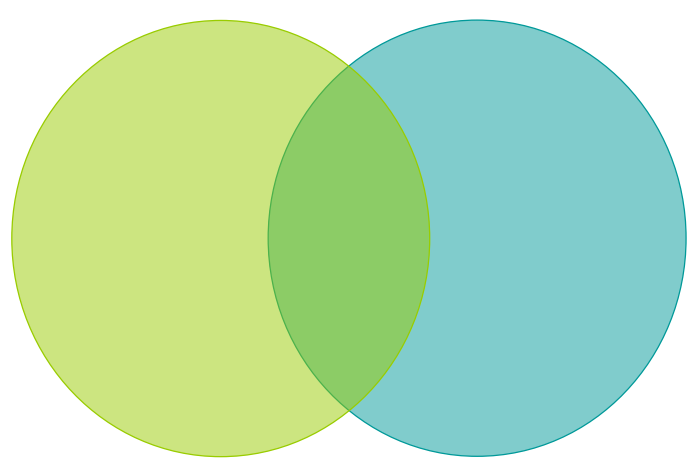

Gambar 4. Diagram Tentang Kreativitas

Seperti juga yang dituliskan oleh Dwi Marianto tentang berpikir dengan rasa meraksasakan rasa. Rasa adalah salah satu dari beberapa daya khusus dari tubuh manusia (Marianto, 2015)

Meraksasakan rasa (esensi dari sesuatu) sesungguhnya merupakan faktor penting dalam merepresentasi ide kreatif (Marianto, 2015).

Atmosfir kreativitas seni itu tanpa batas, melebihi rasionalitas dan imajinasi. Walaupun kreativitas seni itu tanpa batas bukan berarti kreativitas seni itu tidak terukur. Dalam mengukur kreativitas seni, standar ukuran kreativitas seni tidak bisa hanya diukur dari kecerdasan otak semata karena kreatifias seni itu menuntut ukuran yang melebihi kecerdasan otak. Diagram di atas menunjukkan, bahwa pengetahuan dan seni itu setara dan memiliki satu kesamaan yaitu kreativitas, dimana dalam kajian-kajian bio psikologi kreativitas adalah merupakan hasil kerja otak.

Masyarakat Jawa sudah jauh lebih dulu merasakan adanya kecerdasan lain di luar kecerdasan pikiran, oleh Ki Ageng Suryo Mentaram 1892-1962 tokoh psikologi eksistensialis nusantara, tentang ilmu jiwa ini sudah diilmiahkan dengan pandangannya yang mengarahkan, bahwa rasa (raos) itu adalah soul atau jiwa. Hasil perjalanan pengalaman panjang Ki Ageng melahirkan ilmu yang disebut kawruh jiwa, yang pada awalnya disebut kawruh begja, kawruh jiwa adalah ilmu tentang jiwa, jiwa sendiri adalah sesuatu yang tidak kasat mata namun keberadaanya diakui dan dapat dirasakan. Ki Ageng juga mengatakan bahwa kawruh jiwa adalah ilmu tentang raos (rasa) atau kawruh rasa. Tujuan belajar kawruh jiwa adalah agar dapat hidup bahagia, bahagia yang sejati yang tidak tergantung pada waktu, tempat dan keadaan. Kebahagiaan menurut pandangan Ki Ageng didapat justru bukan dari kecerdasan pkiran melainkan dari rasa (raos). Kawruh jiwa adalah ilmu tentang mengolah jiwa dengan rasa, dengan rasa kemampuan meta kognisi (memahami pikiran sendiri) semakin lebih terasah dan terarah, sehingga lebih mampu merasakan perasaan diri sendiri dan orang lain. 
Manusia menjadi lebih bisa menikmati sensasi kasih sayang, mendapatkan nikmatnya sensasi kasih sayang sehingga membawa manusia memiliki kesadaran untuk hidup damai dan bahagia. Damai dengan diri sendiri dan damai dengan lingkungannya. Kesadaran kasih sayang merupakan daya untuk mampu menghidupi kehidupan. Pemahaman dan pengetahuan tentang kawruh jiwa dibutuhkan bagi seorang seniman agar kreativitas seni yang dihasilkannya jauh dari kreativitas yang merusak, melainkan kreativitas itu bersifat membangun dan menyatu dengan pemahaman eco art.

Seorang desainer produk industri memiliki kemampuan kecerdasan mengolah jiwa dan raga, merupakan hal yang wajib dimiliki agar karyakaryanya mampu mendorong inovasi sehingga mampu mempengaruhi pasar, seperti yang dituliskan oleh Bagas Prasetyowibowo dalam Jurnal Desain Produk Industri, bahwa:

Maksud dari pasar disini adalah suatu kondisi atau situasi tentang kebutuhan masyarakat pada barangbarang produk yang dikaitkan dengan masalahmasalah yang timbul, karena adanya tuntutan ke arah perubahan dan pengembangan desain dari satu produk (Prasetyowibowo, 1998).

Berikut juga yang dituliskan oleh Bagas Prasetyowibowo, bahwa tidak selamanya karya dan cipta desain berawal dari permintaan pasar, tetapi ada kalanya desain itu muncul karena adanya inovasi atau kreasi baru, dan karena adanya penelitian serta pengembangan teknologi yang akan mempengaruhi pasar itu sendiri ( Prasetyowibowo, 1998).

Desain disebut berhasil, apabila desain itu mampu mengangkat inovasi dan mempengaruhi masyarakat sehingga dapat menjadi tren dan digemari masyarakat. Desainer dan pasar memiliki model of the world masing-masing dalam dirinya, sehingga desainer dan pasar mempunyai cara penilaian dan pendapatnya sendiri - sendiri terhadap produk yang ditawarkan. Dibutuhkan suatu titik temu antara desainer dan pasar agar produk dapat ditrima pasar. Dalam pengetahuan desain produk hal ini dinyatakan sebagai strategi penggabungan. Strategi penggabungan ini dimaksudkan untuk mengambil jalan tengah atau suatu kompromi ( titik temu) antara permintaan pasar dan keinginan para ahli desain (Prasetyowibowo, 1998).
Banyak cara pendekatan yang dilakukan untuk menerapkan strategi penggabungan, misalnya melalui pendekatan ekonomi, pendekatan perilaku/psikologi dan pendekatan aktivitas harian. Semua pendekatanpendekatan ini adalah pendekatan yang berbasiskan kognitif yang bersifat rasional dan logis. Sesuatu bisa dikatakan rasional dan logis bila bisa dinyatakan secara riil, rasional dan terukur.

Pemahaman tentang kawruh jiwa juga bisa digunakan sebagai sebuah pendekatan dalam menerapkan strategi penggabungan, seperti apa yang dikatakan oleh Edi Joesoef yang dituliskan dalam buku Jurnal Desain Industri.

Pendekatan pasar yang dilakukan tertuang dalam point nomor satu yaitu produk harus mewakili jiwa seseorang atau keluarga Indonesia yang adventure dan suka berekreasi. Dengan kemampuan kecerdasan mengolah jiwa, desainer akan bisa menghasilkan karya yang mewakili jiwa masyarakat karena desainer memiliki kemampuan rasa yang lebih tajam dan terarah.

Dalam buku Psikologi Kepribadian Analisis Seluk beluk Kepribadian Manusia yang ditulis oleh Lynn Wilcox, Molana-al Moazam Hazsrat Shah Maghsoud Sadegh Angha, mengajarkan bahwa untuk menyadari kehidupan dan misterinya pengalaman laboratorium yang bersifat material harus disikapi hanya sebagai perkenalan. Seseorang memulai dengan dunia fisik kemudian melonjak maju kepada metafisika. Meskipun pengetahuan eksperimental telah menyediakan solusi pada masalah-masalah kehidupan fisik, penelitian mereka sangat terbatas untuk menjelaskan fenomena natural (Wilcox, 2013).

Prinsip kognitivisme banyak dipakai dalam pendidikan, termasuk dalam pendidikan tinggi di Indonesia. Teori kognitif adalah teori yang umumnya dikaitkan pada proses belajar. Kognisi adalah kemampuan psikis / mental manusia yang berupa mengamati, melihat, menyangka, memperhatikan, mendengar dan menilai. Dengan kata lain kognisi menunjuk pada konsep tentang pengenalan. Teori belajar kognitif lebih mementingkan proses belajar dari pada hasil belajar itu sendiri. 
RAMM Pandansari KusumoReposisi kecerdasan

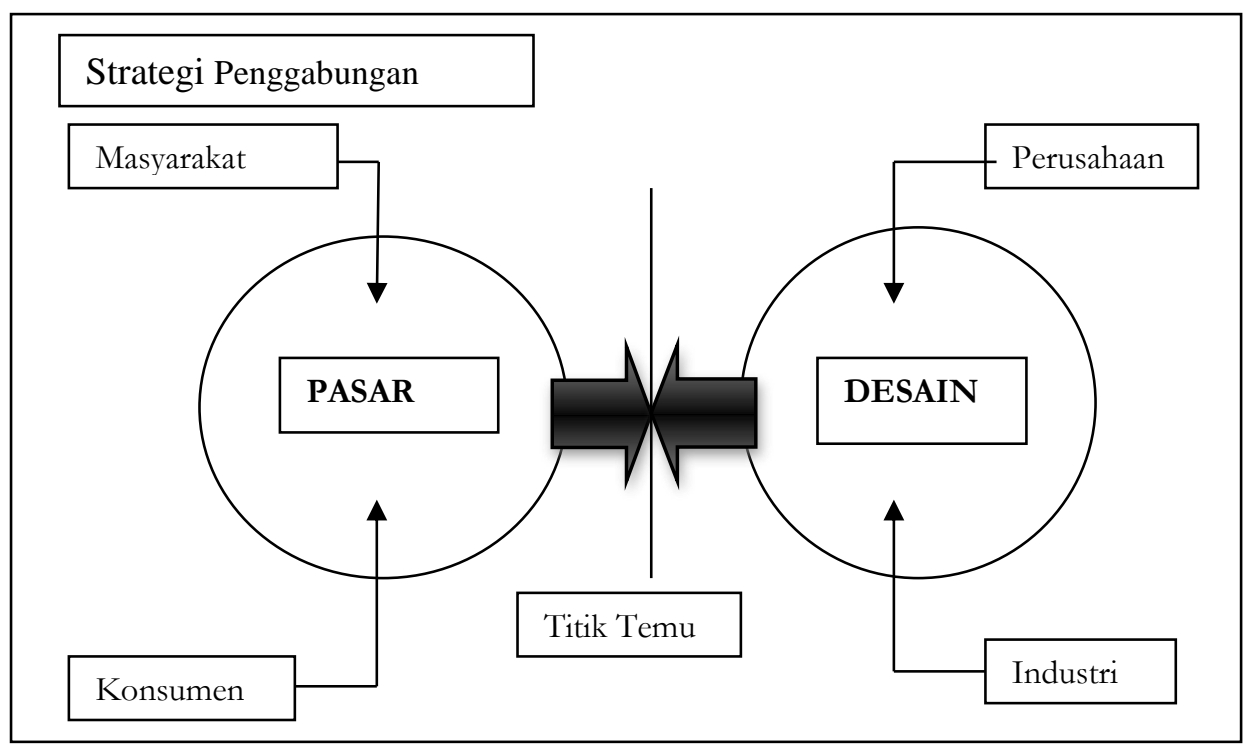

Gambar 5. Bagan Strategi Penggabungan Pasar dan Desain (Sumber: Prasetyowibowo, 1998 hlmn.23)

Cakupan kerja kognitif meliputi panca indra dan otak, kecerdasan kognitif mempercepat perubahan fisik peradaban manusia, bahkan dengan kecerdasan kognitif manusia mampu memodel kecerdasan itu, dengan diciptakannya alat kecerdasan buatan (artificial intelegensi) yang dinamai komputer. Dalam perkembangannya komputer mampu menggantikan kemampuan kecerdasan kognitif manusia. Semua pekerjaan fisik manusia beserta hasil-hasilnya dapat dilakukan oleh komputer. Harus diakui kecerdasan pikiran membuat hidup menjadi semakin mudah, yang rancunya dengan kemudahan hidup itu tidak menimbulkan makna dari hidup dan kehidupan itu sendiri. Integritas dan moral hanya sebagai bahan kajian dan slogan, dengan kecerdasan pikiran dunia seni mengalami perkembangan, api perkembangan dunia seni itu tidak sebanding dengan tumbuhnya local genius. Tumbuhnya perkembangann dunia seni itu akibat dari duplikasi, rekayasa dan modifikasi local genius yang telah dimiliki nenek moyang. Desain produk menjadi kehilangan esensinya karena desain produk hanya berfungsi sebagai alat rasionalitas ekonomi dengan alasan biaya murah karya cipta desain dari kompetitor diangggap milik bersama sehingga terjadi pelanggaran hak cipta. Permasalahan desain tidak hanya soal fisik tapi juga meliputi aspek psikologis dan lingkungannya. Hidup yang menciptakan kebutuhan, desainer harus bisa memandang bahwa kebutuhan itu adalah hidup sehingga pemahaman keberagaman hayati harus melekat dalam kecerdasannya.

\section{Kesimpulan}

Sejak jaman Renaisans hingga saat ini peradaban terkondisikan menggunakan satu kecerdasan yaitu kecerdasan pikiran. Kecerdasan pikiran telah mampu menunjukkan ekistensinya dengan puncaknya kecerdasan pikiran mampu memodel dirinya dengan menciptakan alat kecerdasan buatan (artificial intelegensi). Kecerdaasan pikiran mempermudah kecerdasan fisik manusia dan berkesan mengkaburkan kehidupan non-fisik manusia. Di tengah kekaburan itu kecerdasan pikiran dipaksa untuk menjernihkannya sehingga lahirlah teori-teori dan konsep-konsep yang menjadi alat upaya untuk menjernihkan. Jauh panggang dari api, realita tidak hanya terdiri fisik semata, realita juga terdiri dari non-fisik. Di mana kedua aspek itu saling berkelindan. Sebagaimana alam ini memiliki dua daya, yaitu daya gravitasi dan daya levitasi. Jika selama ini pengetahuan disibukkan tentang daya gravitasi, sekarang pengetahuan disadarkan akan adanya daya levitasi dimana daya levitasi lebih mendasar bagi alam. Begitu pula dengan kecerdasan, kalau selama ini pengetahuan disibukkan oleh pikiran sekarang saatnya pengetahuan mengeksplorasi mencari kecedasan lain. Meditasi adalah contoh yang nyata kecerdasan berpikir tanpa pikiran. Dan kecerdasan bermeditasi membangkitkan daya levitasi. Kecerdasan lokal dapat menjadi pintu gerbang dari pencarian kecerdasan lain. Dalam dunia seni kecerdasan lokal sudah terbukti mampu melahirkan karya adiluhung. Suatu yang tidak logis 
ditengah persaingan masyarakat industri dunia para desainer produk hanya mengandalkan dari keampuhan kecerdasan pikiran yang bersifat global dalam berkompetisi menghadapi pasar global. Para desainer produk harus dibekali dengan kecerdasan lain di luar kecerdasan pikiran dengan metode dan pendekatan lokal (kawruh jiwa). Masyarakat industri di Cina telah menerapkan kecerdasan lokal dalam berkompetisi dengan industri barat. Mereka mengharapkan prinsip tao, sehingga mereka menerima menyadari dan memanfaatkan produk indutri barat yaitu dalam segi kualitas. Mereka memanfaatkan kekuatan dari industri barat sebagai kelemahan bagi produk induastri barat, masyarakat industri cina menerapkan frugel inovation (inovasi biaya murah) yang hasilnya produk industri mereka mulai menguasai pasar dunia.

Kecerdasan kognitif mempercepat pertumbuhan dan perkembangan dunia seni dan berkesenian. Cepatnya pertumbuhan tidak sebanding dengan tumbuhnya local genius yang bisa menghasilkan kembali karya-karya adiluhung dan berdaya hidup. Tidak cukup dengan revolusi mental lakukan revolusi kecedasan dengan memposisikan kembali sumber-sumber kecerdasan yang telah dikaruniai sang Pencipta agar karya-karya adiluhung dan berdaya hidup dapat lahir kembali.

\section{Daftar pustaka}

Joesoef, Edi (2008) Metode Desain Merubah Kendaraan Niaga Menjadi Kendaraan Wisata Pada Kendaraan Jenis Pick-up di Indonesia. Jurnal Desain Industri, Vol. 5 (1), Februari 2008.

LPPSK (Lembaga Pengkajian dan Penerbitan Seni Kriya ISI Yogyakarta), (2009) Prosiding Seminar Nasional Seni Kriya; Kriya: Kesinambungan Dan Perubahan, Percetakan CV. Arindo Nusa Media, Yogyakarta.

Marianto, Dwi (2015) Art \& Levitation. Yogyakarta: Penerbit Percetakan Pohon Cahaya

Prasetyowibowo, Bagas (1998) Desain Produk Industri, Bandung: Yayasan Delapan-Sepuluh, Bina Usaha dan Pengembangan Desain Produk, Departemen Industrial Design Studio.

Pinel, John P.J. (2009) Biopsikologi. Yogyakarta: Pustaka Pelajar.

Pasiak, Taufiq (2009) Unlimited Potency of the Brain. Bandung: PT. Mizan Media Utama (MMU)

Sugiharto, Ryan (2015) Psikologi Raos; Saintifikasi Kawruh Jiwa Ki Ageng Suryomentaraman. Yogyakarta: Pustaka Ifada. (2013) Pengembangan Desain Produk, Jakarta: Direktorat Jenderal Pengembangan Ekspor Nasional Kementrian Perdagangan 